\title{
A NOVICE TEACHER'S PERCEPTIONS OF HER DIFFERENT ROLES AS AN ENGLISH LANGUAGE TEACHER
}

\author{
Irma Windy Astuti \\ Islamic University of Indonesia
}

\begin{abstract}
This paper is a study investigating the different roles of English language teacher as they are particularly perceived by a novice English teacher. I am primarily interested in knowing and understanding how a novice teacher perceives her different roles as an English language teacher given her status as a beginning teacher who may still be relatively new in her teaching profession. Hence, being perceived as a new, and therefore, a lessexperienced one, her accounts and take on her different teaching roles are valuable to leam as they may reflect her pedagogical knowledge, limitations, expectations and the challenges she may face in assuming her different roles as an English language teacher which may as well be quite different from those of more senior or experience English language teachers.

This study is a progressive qualitative. The data, in a form of texts, were presented and analyzed based on the narratives of the research participant. The use of narrative research inquiry was intended to seek insightful meanings and understandings of the individual's perceptions of her different roles as an English language teacher. The data were taken both from interviews and classroom observations.

The findings of this study underline the participant's sound grasp and firm understanding of her various teaching roles and reveal a range of roles she had to perform involving thoughtful considerations of her teaching practices. Based on the findings of this study, it is recommended that a further or subsequent research conducted within a similar topic may also try to solely focus on one of the findings of the perceived teacher's roles in order to gain a deeper insight on it. A probable research may therefore investigate the degree of each role to see how it comes into being, what related factors may come into play and what constraints as well as challenges may come with each and or with all of the teaching role(s). Alternatively, a related study
\end{abstract}


may also attempt for a comparative study investigating the similarities and differences of the various teaching roles perceived by both novice teachers and more experienced teachers. Finally, there may also be a need for an investigation on the students' perceptions towards English language teachers' various and effective roles in relation to their learning.

Keywords: Perceptions, teacher's roles and novice teacher

\section{A. Introduction}

Teaching English as foreign language is a long-standing profession which only sees itself as being in more and more demand throughout the world. With English language being more commonly used in many parts of the world, the demand for English teachers has progressively increased.

The high demand for English language teachers in Indonesia, both in formal and informal sectors, has provided fresh graduates of English education program with an experience of early employment as English language teachers. As a result, there are quite many novice English teachers, including those in Indonesia, embarking on their first and second year of teaching English as foreign language either at primary or secondary levels.

Being new in a profession is not always an easy take. The same is true for novice English teachers. It is since novice teachers are still pretty much considered as in-experienced for they have only limited experience in handling the classroom and its learning dynamic. Bartel mentions that the early years of teaching are often characterized by a "sink-or-swim" or "survival" mentality because we have often failed to provide for careful support and thoughtful development of teaching expertise over time. He further asserts that another challenge faced by beginning teachers is since they are also traditionally expected to assume all the same responsibilities as the more experienced teachers (2004:3)

For that reason, I am iñterested in investigating a novice teacher's perceptions on her different roles as an English language teacher. I am interested in understanding how the beginning teacher articulates her various teaching roles which is at the same time mirror her pedagogical knowledge, expectations and quite possibly, a mixture of challenges that she may encounter in her real teaching practice as a new teacher. 
As far as my study is concerned, there has been well reported studies in the literature about the teacher's experience in their initial years; however, less documented in second and foreign language teaching literature (Almarza, 1996; Johnson, 1998; Richards, 1998). Furthermore, there may not be previous studies on novice English teachers whose focus is on investigating their perceptions on the different roles of English language teacher.

\section{B. Research Question}

It is inevitable that anyone embarking on a teaching job is soon required to assume different teaching roles as the profession comes with many responsibilities and it is there to meet certain expectations. Meanwhile, teaching English as a foreign language has become a reality for many novice teachers who are equally assumed to articulate various roles in teaching.

Therefore, this study specifically aims at investigating and finding answers to the question of how a novice teacher perceives her different roles as an English language teacher.

\section{NoviceTeacher}

According to Storm (1989), a novice teacher is a teacher education program graduate entering teaching. In most literature on novice teaching, the initial entry years is normally one to three years.

On average, regardless the number of years, those initial years of teaching are much considered by novice teachers as a bewildering period. The challenges that generally typify novice teachers' early teaching and employment derived from their unfamiliarity of their new teaching job. Bartel (2004) mentions that the early years of teaching are often characterized by a "sink-or-swim"or "survival" mentality because we have often failed to provide for careful support and thoughtful development of teaching expertise over time. In the same way, Copa (1991) argued metaphorically:

Each new teacher enters the classroom more or less as a stranger in a strange land. The suitcases he or she carries are filled with articles from the old country, the familiar land just left. 
Another challenge that may as well be faced by novice teachers is due to the responsibility that is bear upon them. Bartel asserts that beginning teachers are often traditionally expected to assume all the same responsibilities as the more experienced teachers (2004:3). The amount of responsibility that novice teachers have to bear is also identified by (Richards, 1998; Roberts, 1998; Kagan, 1992). That is, among others, heavy teaching and non-teaching workload, and insufficient facilities that affect their teaching performance.

In addition to the challenges which are likely to be encountered by novice teachers, they are also seen as having distinctive characteristics and attributes given their novice experience. Referring to Fuller's four stages of teachers' development (1969), novice teachers seem to fall into the first or initial stage where in this first stage or also known as a pre-teaching concerns stage that pre-service teachers start to get a sound grasp of their roles as educators. As with the different roles that the novice teacher is starting to assume, many of those roles may as well have a lot to do with their teaching context which can both enable and limit new teachers' chances to apply what they got in their teacher preparation program which has shaped their vision (Bullough et.al, 1993)

\section{Teacher's Perception}

Klazky's (1984), as cited in Woolfolk (1999), defines perception as the processes of determining the meaning of what are sensed. In the same vein, Kauchak (2001) sees perception as the process by which people attach meaning to experiences. He explained that after people attend to certain stimuli in their sensory memories, processing continues with perception. The term "apperception" can also be used under pedagogic context which means the act of taking into the mind (Kauchak, 2001).

Kauchak also explained that perception cannot be done in vacuum for background knowledge in the form of schemas affects perception. This is also saying that perception manifests alongside with and is very much influenced by some background information. Research findings have also corroborated this claim that background knowledge resulting from experience strongly influence perception (Glover et al., 1990). 
In the context of teaching, perception is hence considered as an important variable for it helps teachers attach a given meaning to stimuli in their classroom environment, in the learners' behavior, and even in his/ her own teaching experience and classroom practice. In this sense, perception can thus aid and strengthen teachers' understanding towards his/ her classroom practice consecutively suggesting how he/ she should function effectively. As cited in Ahmad \& Aziz's (2009), several past research have shown that thinking or perception plays an important part in teaching. The teachers' perception and observation of his/ her classroom situation and classroom practice will in turn contribute much to the teaching-learning process by providing suggestions and directions for teachers' future improvement. In other word, perception help raise teachers' awareness in evaluating the whole teaching process; examining the teacher's understanding of his /her decision makings and classroom practice. Respectively, Borg (2006) mentions the importance of having a consciousness of "what specifically it means to be a language teacher" (p. 3) for as such is one of the qualities that a reflective teacher should possess (Nunan and Lamb, 1996). Nunan and Lamb furthered that reflective teachers are ones who are capable of monitoring, critiquing and defending their actions (p.120).

\section{E. Teacher's Roles}

The concept of 'role' has become very popular in ELT and is a term in common usage to denote the functions that teachers and learners perform during the course of a lesson. In social setting of classroom, teachers' expectation on teaching and learning will determine the appropriate functions that teacher must perform (Hedge, 2007: 28). Similarly, Roger (1961) as cited in Harmer (2007: 108) also put emphasis on the need to be always 'congruent'. In this sense, teacher is expected to be always fitting him/ herself to the learners' learning needs or classroom situations.

In the mean time, the degree to which teachers are expected to be appropriate and congruent can mean taking up various kind of roles. Using a framework suggested by Harmer (1991), it is possible to identify teachers in a number of roles in the lesson: teacher as controller, assessor, corrector/ provider of feedback, organizer in giving instruction, initiator, prompter, and resource. In this sense, Harmer's framework of the teachers' roles deals exclusively with roles that relate to 
classroom procedures. Other framework a study undertaken by (Karavas-Dukas 1995) offers categories that moved beyond the immediate pedagogic concerns into the areas much influenced by attitudes in social and cultural environment (Hedge, 2007: 27). The followings are categories of teachers' roles yielded from the study conducted by Karavas-Dukas (1995): facilitator of learning (64.2\%), source of advice (53.5\%), source of expertise (46.4\%), management roles (35.7\%), caring roles $(25 \%)$, sharing roles $(17.8 \%)$, creator of classroom atmosphere $(14.2 \%)$, and evaluator $(10 \%)$.

It is interesting to see how considerably varied the roles that teachers should adopt, both directly in relation to classroom and social practice. It is therefore considered to be unacceptable to stick to one mode of behavior as it easily denies the teacher's self and the students' access and possibilities to meaningful teaching and learning (Harmer, 2007:109). In Ayers' all inclusive view (1993:5), teaching is spectacularly unlimited:

"Teaching is instructing, advising, counseling, organizing, assessing, guiding, showing, managing, modeling, coaching, disciplining, prodding, preaching, persuading, listening, interacting, nursing, and inspiring. Teachers must be experts and generalists, psychologists and cops, rabbis and priests, judges and gurus."

The virtually numerous qualities suggested about the teachers' roles have made teaching tremendously a challenging profession. The wide range of roles that teacher should take on ultimately suggest the dynamic of learning and the diversity of learners and learning that teachers have to deal with.

\section{F. Method}

There have already been a number of similar studies investigating novice English teacher with either qualitative or quantitative method employed in the study of the related topic. As with this study, my intention is to gain rich and revealing data about my participant, a novice teacher, on her perceptions of the different roles of English language teacher.

I am interested in pursuing and understanding her perceptions, beliefs, experiences, meanings and realities by way of narrating her stories, feelings, opinions, and experiences, and to connect and interpret them. 
Based on such considerations and motives, the progressive qualitative research paradigm seems to fit my research agenda in obtaining the kind of result and the level of depth that I wish to have. It is since qualitative research mainly concerns with investigating areas in social life backgrounds, interest and broader social perceptions- and therefore presents a statement about reality and social life (Holliday, 2002: 38). In addition to that, progressive qualitative researchers 'portray people as constructing the social world' and the researchers as 'themselves constructing the social world through their interpretation of it' (Hammersley and Atkinson, 1995).

As with this study, it tries to follow narrative interpretive inquiry as a way of understanding experience in which stories and interpretation were constructed to build meanings and understanding (Clandinin and Conelly, 2000: 20; Creswell, 2003). Furthermore, Fivush (2006) adds that

Narratives move beyond the simple description of experienced events to provide explanatory frameworks and emotional evaluation of what these events mean to the individual. More specifically, narrative allows us to create shared reality. Through telling the stories of our lives, we are telling who we are and are sharing our view of the world. We do not simply tell what happened; we explain how and why these events occurred, how we thought and felt about them and what they mean to us.

As with the use of narrative inquiry in the field of foreign language teaching and learning, it may, for instance, be used to investigate a teacher of EFL and her perceptions of her own classroom with the main objective was to better understand the foreign language classroom and the participants' experiences from the teacher's point of view (More, 2000). In a view of that, for instance, Freeman is firm that there has been the need to study, to understand, and in a sense to define teaching; this includes coming to understand the role and the person of the teacher (1996: 360). He further asserts:

To bridge the gap and to fully understand teaching, we must take an approach which puts the person who does the work at the center... what teachers know, and how that knowledge finds its way into their practice, must become a vital concern of those who want to understand and influence education (1996b:90)

In line with the concepts, this study attempts to provide answers to the research questions by seeking stories, perceptions, motivation, and feelings of the 
participant, reporting and interpreting them as a way of understanding the participants' motive and beliefs underlying their attitudes, actions and practice.

As with the participant of this study, the variety and richness that I could obtain from the participant is due to its relevant representation of the sort of participant that meets the characteristics of a novice English language teacher.

The involvement of one novice teacher participant in this study certainly was carefully thought of. It means that, having had only one participant, I had to make sure that I would diligently and profoundly elicit as much rich data as possible from her. The fact that I had known her and had been involved with her and few of her students in an English language project had made it easy for me to reconnect and get familiar with her. I could say that we built good rapport and understanding almost immediately and so effortlessly.

Meanwhile, since the data collected from this study functions both as evidence and clues, it is important that researcher conducting a qualitative study is to obtain rich and accountable data which can be made possible by getting or collecting them from various sources. Patton (2002:306) argues,

"Multiple sources of information are sought and used because no single source of information can be trusted to provide a comprehensive perspective...by using a combination of observations, interviewing, and document analysis, the fieldworker is able to use different data source to validate and crosscheck findings."

The view is supported by Marshall and Rossman, "Each type and source of data has strengths and weaknesses. Using a combination of data type increases validity as the strengths of one approach can compensate for the weaknesses of another." (1989: 79-111)

Given the understanding on the importance of gathering various types of rich data from different sources, I determine to collect and use all the recommended types of data to achieve wholeness in the data to ensure and support the validity of my analysis. So, this research will gather data from interviews and classroom observations.

This study additionally follows Creswell's model (2003: 191) in employing several procedures for acquiring intended research data. The first step is a preliminary interview performed to project and generate the map of the research 
while anticipating the probable research problems. The second step involved making lists of un-structured interviews questions, which were based on the previous preliminary interview, the map of the research and some references to related studies and literature. The third step was the in-depth (structured) interview which was performed to gain deeper information while checking back, confirming and exploring the earlier facts and findings from the set and the research participant. The fourth step included class observation to get the description of behavior, events and interaction. I also keep in mind the anticipation for emergent data that may as well be important to be taken into account.

Having collected a vast array of data from different sources by way of employing several techniques, the next crucial step to be carried out is the analytic task - making sense out of the collected materials. This, among others, includes organizing the data, reading the data, coding process, using the coding process to generate description/ themes about participants, setting, and events, narrating the descriptions and themes, and interpreting the data (Creswell, 2003)

\section{G. Findings}

The discussions on the concepts espousing novice teachers and the roles of English language teacher coupled with the accounts and perceptions of the novice teacher participant on her roles as an English language teacher can be summed up in the following table that describes and outlines the elements of the theoretical discussions and findings: 
Table 1. Lists of Novice Teacher's Perceptions on Her Different Roles as an English Language Teacher

\begin{tabular}{|c|c|c|c|}
\hline Theme & Sub-theme & Specifications & Codes \\
\hline \multirow[t]{3}{*}{ Teachers' roles } & $\begin{array}{l}\text { Teacher as } \\
\text { Facilitator of } \\
\text { Learning }\end{array}$ & $\begin{array}{l}\text { Teacher as Material } \\
\text { developer } \\
\text { Teacher as (re)Source / } \\
\text { Language model } \\
\text { Teacher as Evaluator/ } \\
\text { assessor } \\
\text { Teachers as Counselor }\end{array}$ & $\begin{array}{l}\text { TEA FCLTATR - } \\
\text { MATRL DEV } \\
\text { TEA FCLTATR - } \\
\text { SOURCE } \\
\text { TEA FCLTATR - } \\
\text { EVAL } \\
\text { TEA FCLTATR - } \\
\text { COUNSL }\end{array}$ \\
\hline & $\begin{array}{l}\text { Teacher as } \\
\text { Classroom Manager }\end{array}$ & $\begin{array}{l}\text { Teacher as Organizer/ } \\
\text { controller } \\
\text { Teachers as Instructor }\end{array}$ & $\begin{array}{l}\text { TEACM - ORGNZR } \\
\text { TEA CM INSTR }\end{array}$ \\
\hline & $\begin{array}{l}\text { Teacher as having } \\
\text { Special Role }\end{array}$ & $\begin{array}{l}\text { Teacher as Participant } \\
\text { of Leaming } \\
\text { Teacher as Motivator }\end{array}$ & $\begin{array}{l}\text { TEA SPECIAL - } \\
\text { PART } \\
\text { TEA SPECIAL - } \\
\text { MOTIV }\end{array}$ \\
\hline
\end{tabular}

As it is expected from every teacher, my teacher participant, also seemed to play and perceive herself as having multiple roles.

\section{Teacher as Facilitator of Learning and Classroom Manager}

The teacher is by far the most important figure in the classroom. Being engaged in large class teaching, my novice teacher participant recognized the different roles that she had to articulate. She identified some of her roles as a material developer, language model, assessor and a counselor.

"We have a formal book... I teach the material from the book, but I also add and use other material that I have created. I imagine the life of teenagers, what is it like... after all I used to be a teenager myself, not long ago... What would teenager do? I searched and downloaded the material from the internet, I compiled them and made them into hand-out" (Unstruct/ TEA FCLTATR-MATRLDEV)

"...because I think it is important to make them interested in the material that we use... So, what is it... it won't make them bored. English materials have to be made varied..."(Struct/TEA FCLTATR-MATRLDEV) 
Table 3. Excerpt of researcher's field-work report/ observation

\begin{tabular}{|lll|}
\hline Researcher's Notes & Descriptions & Codes \\
\hline o & $\begin{array}{l}\text { At 1:15 The students started to form } \\
\text { groups and worked together on their } \\
\text { dialogue }\end{array}$ & EVAL \\
o At 1:40 - The teacher got up from \\
her chair and went to double check \\
each groups' progress \\
The teacher moved around to ask if \\
$\begin{array}{l}\text { her students had understood the } \\
\text { procedure }\end{array}$ \\
One of the girls from one of the \\
$\begin{array}{l}\text { groups showed their dialogue draft to } \\
\text { the teacher 'she checked it, read it }\end{array}$ \\
$\begin{array}{l}\text { while answering questions from other } \\
\text { students) }\end{array}$ \\
\hline
\end{tabular}

Another important role that my teacher participant also had to take up was a counseling role. The students often came to her to consult about their problems related to learning English. This counseling would take place both in and outside the classroom.

"They often ask me... Miss, how to study English well? How can we be fluent in English? Sometimes they ask, Miss, please talk to me in English more often."(Struct/TEAFCLTR COUNSL)

"...but this one was very quiet, she's so silent, so I asked, what's the problem? Most students are afraid and embarrassed if they look stupid, the class would make fun of them... and sometimes, after we finish the class, that student came to me... She said she didn't understand the lesson, I said, Ok! and then, I discuss it with her, we solve her problem together." (Struct /TEA FCLTR COUNSL)

The roles that my novice teacher participant had to play were certainly varied and she seemed to be quite aware of the possible responsibilities and requirements that came with each of the roles. 


\section{Teacher with Special Roles}

Besides the formal teacher's roles that my teacher participant was required to articulate, a less formal yet, equally important roles were also expected out of her. She recognized that she was also supposed to play special roles for her students which were no less important than the formal ones. She particularly saw herself many times as a motivator and a participant of learning for her students.

"Yes, of course, because I must understand them, if they do not understand what I say, what I want, what they must do, so I will change my role as teacher, I can be 'a student', this is for instance to give the example, and or role-play with them, when they understand my example and know how to do it, I then resume my role as teacher." (Struct/TEA FCLTATR-PART)

"I encourage them to study more with simple and easy activities, for example: face gym, (laugh) watching movies, listening to English songs and remembering the song's lyric like that... reminding them that it's easy to do." (Struct/TEA FCLTATR-MOTIV)

"So, I advised them concerning with their psychology. Besides that, there is also rewards and punishments to motivate them. When they have become more diligent and have done well with their tasks, they asked the reward from me... So, Ididn't just give punishment... (Struct/TEA FCLTATR-MOTIV)

The above excerpts suggest that the teacher's ability in providing additional assistance, attention and motivation to her students could be considered valuable assets. Hence, the teacher's attention and her ability stand equal as participant of learning would help increase her students' aspiration in learning English.

During the process of my data collection, I indeed came across to a number of emergent themes for my study. The following table shows the list of the emergent themes of this study. The themes that emerged showed yet other roles of English language teacher as they are perceived by my novice teacher participant, namely teacher as a negotiator and a peer to her learners. 
Table 4. Illustrated List of Emergent Themes

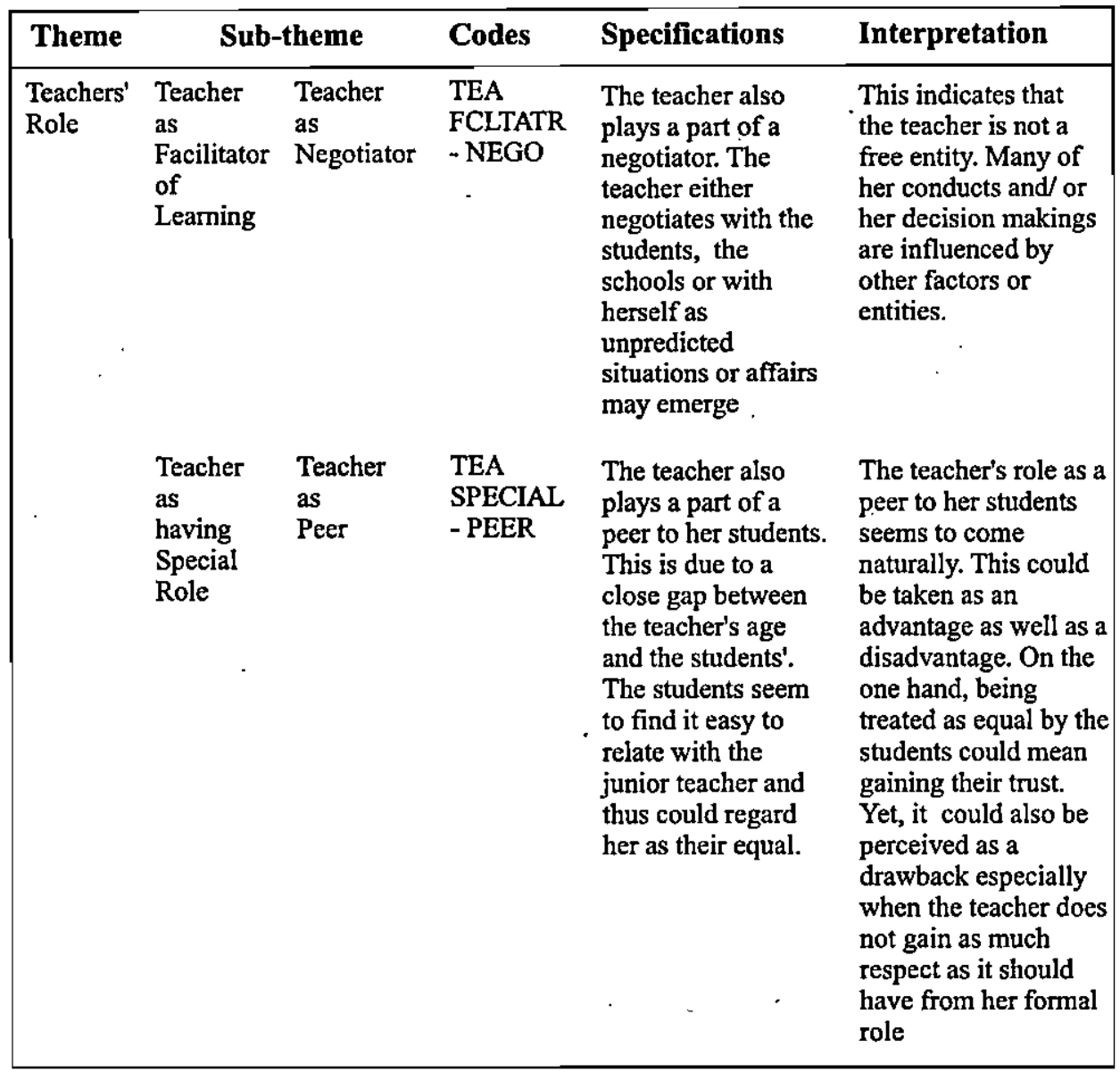

\section{Teacher as Negotiator}

My teacher participant admitted that since she was much involved in many decision making process and problem solving, she certainly could not escaped from dealing with situations in which she was required to negotiate. This consideration for and acts of negotiating was both at the institutional level and related to her classroom teaching. An instance of this negotiation process involving my teacher participant's negotiation with her students is as seen in the following excerpt: 
“. I want to know why they boycott my class... They finally confessed that they wanted me to be less serious... and not so strict and not harsh to them. Finally, we had a mutual understanding. I become calmer now, and so far it worked well between us.". (Unstruct/TEAFCLTATR-NEGO)

The above extract shows how my novice teacher participant was required and expected to reach an agreement with her students about the way she was expected to teach and treat them. I particularly see this instance as something interesting. The fact that the students could 'force' or make her attend to their demand also suggests the students' familiar or less formal association with the teacher. Given the relatively small age gap between my teacher participant and her students', and considering her junior status as a beginning teacher, it seemed uncomplicated and less intimidating for the students to negotiate with her.

Other than the act of negotiating that my teacher participant had to make with her students, a negotiation involving the school authority related with her teaching conduct was also apparent, as seen in the following extract:

"Pressure? not personally...Mmm, but the school indeed set a target for a minimum score... it must be at least or minimum of $6 . .$. Because the school has set the target, so I make sure I talk about it with the students... and usually before we face the final examination, we still undergo teaching and learning process. Especially, in the $I^{\text {st }}$ semester.. the materials I give to them are usually referring to the materials from the previous final exams." (Struct/TEAFCLTATR NEGO)

It is somewhat clear that my teacher participant was expected to strike some balance between herself and her teaching conduct by way of acknowledging and adjusting to different interests both at classroom and institutional levels.

\section{Teacher as Peer}

The small age gap between my teacher participant's and her students' also almost naturally earned her a new role. She was sort of becoming her students' equal or peer:

"... not all students trusted their problems to the counseling teacher... some of them prefer me... they are supposed to ask about English subject, but they also told me about their personal problems." (Struct/ TEA FCLTATR PEER) 
"In or outside the class, I also felt like I am their friend, their sister, and their teacher too... I can tell them like I am a sister to them, telling them about the importance of doing good." (Unstruct/TEAFCLTATR PEER)

The above extracts suggest an interesting role and relationship which were shared between my teacher participant and her students. It is worth pointing out as this kind of friendly relationship is likely to develop exclusively between a novice teacher and her students who are only few years younger than her. This was as pointed out by Dunne (1993: 114 - 115) in her study involving beginning teacher which suggested that pupils may see the teacher 'more as friends' and that it was possible to be authoritative whilst retaining a friendly relationship with them.

\section{H. Conclusion and Recommendation}

My attempts in trying to make sense of the novice teacher's perceptions on her different teaching roles have enriched and reshaped my understanding of her endeavor. Many of the aspects revealed from her perceptions of her roles as English language teacher have also validated the results of some previous studies within similar topic. Those are particularly related to the roles of teacher as the facilitator and motivator of learning

In addition to the corresponding findings, I manage to get relatively an interesting insights from this study. Among the various roles that my teacher participant had to articulate, her role as peer to her students is quite interesting to learn. This is particularly true as both teacher and students have only small gap in terms of their age. This particular role can be seen as a valuable asset to aid her teaching and interaction with her students without necessarily undermining her formal and legitimate role as an educator. Similarly, my teacher participant also particularly saw this role as an advantage through which she could earn the students' trust and their good sentiment in order to bridge any teaching shortcomings in her initial years.

I also previously held a belief that beginning teacher may not necessarily be fully able to articulate and perceive a firm resolution of her various roles given her relatively new teaching venture. In her reality, my novice teacher participant has in fact developed a sound grasp of effective teaching roles which she needed to assume and articulate in her English language teaching practice which are likely to be both derived from the pedagogical knowledge which she gained from the teacher education program and her initial English language teaching experience. 
To correspond with the conclusion and the implication of the findings of this study, my recommendation would be that of a theoretical and practical one:

1. A further or subsequent research conducted within a similar topic may also try to solely focus on one of the findings of the perceived teacher's roles in order to gain a deeper insight on it. A probable research may therefore investigate the degree of each role to see how it comes into being, what related factors may come into play and what constraints as well as challenges may come with each or with all of the teaching role(s). Furthermore, it is also recommended that further studies may also attempt for a comparative study to show the similarities and differences of the various teaching roles as they are perceived by both novice teachers and more experienced teachers. Also, there may be a need for an investigation on the student's perceptions towards the different roles of their English language teachers. In addition, a further research investigating a similar topic may employ more than one teacher participant identified as providing rich information, having germane profile and reflective ones in order to get a maximum variation from which the researcher could yield more diverse and thorough findings which later contribute to the richness of the intended study.

2. In a more practical level, the findings may also find themselves implicated with the school authorities and institutions to provide necessary support and assistance to their novice English teachers as to orient them concerning with their future employment and responsibilities at the respective school, especially when each school may have its specific constraints and challenges

\section{REFERENCES}

Akbulut, Yavuz. Exploration of the Beliefs of Novice Language Teacher at the First Year of Their Teaching Endeavors. 2003. . Anadolu Universitesi Egitim Fakultes

Ayers, William. 1993. To Teach: The Journey of a Teacher. New York: Teacher College, Columbia University 
Bailey, M. Kathleen., and David Nunan. (Ed.). 1996. Voices From the Language Classroom. New York: Cambridge University Press.

Bennet, Neville., and Clive Carre.(Ed.). 1993. Learning to Teach. London: Routledge.

Bismoko, J. 2007. Foundations of Research in English Language Studies and Social Sciences. Yogyakarta: sanata Dharma University.

Brown, H. Douglas. 2001. Teaching by Principles. New York: Longman

Cresswel, John.W. 2003. Research Design. London: Sage Publication.

Eggen P., and Kauchak D. 2001. Educational Psychology: Windows on classrooms. New Jersey Prentice Hall, Inc

Glover J, Ronning R., and Bruning R.1990. Cognitive Psychology for Teachers. New York: Macmilan

Harmer, Jeremy. 2007. The Practice of English Language Teaching. New York: Pearson Longman

Hedge, Tricia. 2000. Teaching and Learning in the Language Classroom. New York: Oxford University Press.

Holliday, Adrian. 2002. Doing and Writing Qualitative Research. London: Sage Publication

Patton, Michael Quinn. 2002. Qualitative Research and Evaluation Methods. London: Sage Publication.

Walter, Teresa. 2004. Teaching English Language Learning. New York: Longman 